\title{
Penerapan Model Problem Based Learning (PBL) Berbantukan Program Adobe Flash Terhadap Kemampuan Siswa Memecahkan Masalah Materi Getaran Dan Gelombang
}

\author{
Riswanto, Sri Fatmawati \\ Pogram Studi Tadris Fisika, Jurusan Pendidikan Matematika dan Ilmu Pengetahuan Alam, Institut \\ Agama Islam Negeri Palangka Raya, Palangka Raya, Kalimantan Tengah, Indonesia. \\ Email: riswangntg@gmail.com
}

\begin{abstract}
Abstrak
Penelitian ini bertujuan untuk mendeskripsikan kemampuan siswa dalam memecahkan masalah, hasil belajar siswa, dan aktivitas siswa setelah dilaksanakan model Problem Based Learning (PBL) berbantukan Program Adobe flash pada Materi Pokok getaran dan gelombang. Penelitian ini merupakan penelitian deskriptif dengan pendekatan kuantitatif. Instrumen yang digunakan adalah tes kemampuan memecahkan masalah, tes hasil belajar kognitif siswa, lembar pengamatan aktivitas siswa. Populasi penelitian adalah kelas VIII semester 2 MTs Islamiyah Palangka Raya, sampel penelitian adalah kelas VIII-D berjumlah 21 orang. Berdasarkan analisis hasil tes kemampuan siswa dalam memecahkan masalah didapatkan nilai rata-rata pretest 18,42 dan nilai rata-rata posttest sebesar 53,79. Berdasarkan analisis gain dan $\mathrm{N}$-gain menunjukkan bahwa kemampuan siswa dalam memecahkan masalah mengalami peningkatan setelah dilaksanakan model Problem Based Learning (PBL) berbantukan Program Adobe flash didapatkan nilai sebesar 0,43 dengan kategori sedang. Berdasarkan analisis tes hasil belajar kognitif siswa didapatkan nilai rata-rata pretest 39,12 dan nilai rata-rata posttest sebesar 78,57. Berdasarkan analisis menggunakan rumus ketuntasan belajar secara individual dan klasikal didapatkan ketuntasan siswa secara individual sebesar $76 \%$ tuntas dan $24 \%$ tidak tuntas dan secara klasikal dikatakan tuntas, berdasarkan analisis gain dan $\mathrm{N}$-gain menunjukkan bahwa hasil belajar kognitif siswa mengalami peningkatan setelah di dilaksanakan model Problem Based Learning (PBL) berbantukan Program Adobe flash termasuk dalam kategori sedang dengan nilai sebesar 0,65. Aktivitas siswa pada pembelajaran fisika secara keseluruhan dengan model Problem Based Learning (PBL) berbantukan Program Adobe flash termasuk dalam kategori sangat baik dengan persentase nilai rata-rata sebesar $85,73 \%$.
\end{abstract}

Kata Kunci : Model Problem Based Learning, Adobe flash, Kemampuan Memecahkan Masalah, getaran dan gelombang.

\begin{abstract}
This study aims to describe students' ability to solve problems, student learning outcomes, and student activities after implementing the Problem Based Learning (PBL) model assisted by the Adobe Flash Program on the subject matter of vibrations and waves. This research is a descriptive study with a quantitative approach. The instrument used was a problem-solving ability test, student cognitive achievement test, student activity observation sheet. The study population was class VIII semester 2 MTs Islamiyah Palangka Raya, the research sample was class VIII-D totaling 21 people. Based on the analysis of the results of the test students' ability to solve problems, the pretest average score was 18.42 and the posttest average score was 53.79 . Based on the gain and N-gain analysis, it shows that the student's ability to solve problems has increased after implementing the Problem Based Learning (PBL) model assisted by the Adobe Flash Program, the score is 0.43 in the moderate category. Based on the analysis of the students' cognitive learning outcomes test, the pretest average score was 39.12 and the posttest average score was 78.57. Based on the analysis using the individual and classical learning completeness formula, it was found that individual students' completeness was $76 \%$ complete and $24 \%$ incomplete and classically said to be complete, based on the gain and N-gain analysis showed that the student's cognitive learning outcomes increased after the Problem model was implemented. Based Learning (PBL) assisted by the Adobe Flash Program is included in the medium category with a value of 0.65 . Students' activities in physics learning as a whole using the Problem Based Learning (PBL) model assisted by the Adobe Flash Program are included in the very good category with an average score percentage of $85.73 \%$.
\end{abstract}

Keywords: Problem Based Learning Model, Adobe flash, Problem Solving Ability, vibration and waves. 


\section{PENDAHULUAN}

Ilmu Pengetahuan Alam (IPA) merupakan ilmu pengetahuan yang diperoleh dari hasil pemikiran dan penyelidikan melalui metode ilmiah. Fisika merupakan salah satu cabang dari IPA, dan merupakan ilmu pengetahuan yang berkembang melalui langkah-langkah observasi, perumusan masalah, penyusunan hipotesis disertai eksperimen, penarikan kesimpulan serta penemuan teori dan konsep (Trianto, 2010). Proses pembelajaran fisika lebih menekankan pada pemberian pengalaman secara langsung untuk mengembangkan kompetensi agar siswa dapat memahami kejadian yang berhubungan dengan aktivitas di kehidupan nyata secara ilmiah (Nurlaila dkk, 2013).

Ilmu pengetahuan dan teknologi (IPTEK) telah berkembang dengan pesat saat ini, seiring dengan itu Teknologi Informasi dan Komunikasi (TIK) juga ikut berkembang. Perkembangan TIK ini memberikan pengaruh dalam berbagai aspek kehidupan manusia, termasuk diantaranya dalam bidang pendidikan. Dalam bidang pendidikan, pengaruh perkembangan TIK dapat dilihat dengan penggunaannya sarana pendukung proses pembelajaran. Salah satunya adalah dengan mengunakan komputer sebagai alat bantu dalam proses belajar mengajar. Komputer dapat digunakan untuk membantu guru dalam menyajikan bahan ajar, melakukan simulasi seperti animasi bahkan menunjukkan fenomena alam yang terjadi sesungguhnya.
Proses belajar mengajar merupakan proses kegiatan interaksi antara dua pihak yakni siswa sebagai pihak yang belajar dan guru sebagai pihak yang mengajar, dengan siswa sebagai subyek pokoknya. Dalam pembelajaran akan selalu ada interaksi dan komunikasi yang terjadi antara guru dan siswa. Salah satu variasi dalam meningkatkan interaksi dalam proses pembelajaran adalah dengan memvariasikan cara mengajar dalam kelas dan media pembelajarannya yakni model problem based learning berbantukan program adobe flash (Setiawan, 2013). Fungsi media pembelajaran adobe flash yaitu sebagai alat komunikasi berbasis computer guna meningkatkan efektivitas proses pembelajaran.

Adobe flash merupakan suatu program yang digunakan untuk membuat animasi grafis dan animasi yang keberadaannya ditujukan bagi pecinta desain dan animasi untuk berkreasi membuat animasi dan presentasi dalam pembelajaran. Adobe flash merupakan salah satu sarana yang digunakan oleh guru untuk menyampaikan materi ajar yang akan disampaikan kepada siswa. Adobe flash memiliki peran yang penting dalam kegiatan belajar mengajar. Ketika guru kesulitan untuk menyampaikan materi abstrak secara lisan, contohnya seperti materi gelombang. Adobe flash dapat membantu siswa untuk memahami materi tersebut dan menerima penjelasan yang lebih mudah dimengerti

Mata pelajaran fisika memiliki potensi yang sangat besar untuk dijadikan sebagai 
sarana mengembangkan kemampuan. Salah satu kemampuan yang dapat dikembangkan adalah kemampuan berpikir tingkat tinggi yang dilihat dari kemampuan memecahkan masalah siswa. Kemampuan memecahkan masalah diartikan sebagai kemampuan individu dalam proses berpikir guna memecahkan masalah yang ditemui melalui pengumpulan fakta-fakta, analisis informasi, menyusun berbagai alternatif pemecahan masalah, dan memilih penyelesaian yang paling efektif (Yamin, 2008). Kemampuan memecahkan masalah sangat diperlukan dalam kehidupan. Seseorang yang mempunyai kemampuan pemecahan masalah akan mampu menyelesaikan berbagai masalah, baik masalah yang sederhana maupun masalah yang lebih kompleks. Oleh karena itu, kemampuan pemecahan masalah sangat perlu untuk dikembangkan dalam pembelajaran disekolah.

Problem Based Learning (PBL) adalah suatu model pembelajaran yang melibatkan siswa untuk memecahkan suatu masalah melalui tahap - tahap metode ilmiah sehingga siswa dapat mempelajari pengetahuan yang berhubungan dengan masalah tersebut dan sekaligus memiliki keterampilan untuk memecahakan masalah. Problem Based Learning diharapkan dapat meningkatkan kemampuan siswa dalam memecahkan masalah (Annovasho \& Budiningarti, 2014). Penelitian sebelumnya mengenai penerapan model Problem Based Learning untuk meningkatkan kemampuan pemecahan masalah fisika. Diperoleh bahwa penerapan model Problem Based Learning dapat meningkatkan hasil belajar dan kemampuan pemecahan masalah fisika (Juniarti dkk, 2014).

Berdasarkan hasil observasi melalui sebuah pengamatan dan wawancara yang bertujuan untuk mengetahui keadaan sekolah, sarana dan prasarana, proses pembelajaran guru dan siswa di MTs Islamiyah Palangka Raya dan hasil belajar siswa, keadaan sekolah dan sarana prasarana yang ada di Madrasah Tsanawiyah Islamiyah Palangkaraya tersebut, tidak memiliki laboratorium dan sarana prasarana yang kurang, sedangkan proses pembelajaran fisika yang terjadi di MTs Islamiyah Palangka Raya tersebut, jika dilihat kondisi siswa kurang begitu aktif selama pembelajaran berlangsung. Siswa cenderung jenuh dalam belajar pada mata pelajaran IPA Fisika khususnya. Jika dilihat dari guru dalam memberikan pembelajaran IPA fisika khususnya masih monoton dan belum pernah dilakukan pembelajaran menggunakan model PBL dikarenakan tidak adanya laboratorium dan sarana prasarana yang kurang. Hasil belajar fisika di MTs Islamiyah Palangka Raya kelas VIII rendah dimana nilai rata-rata seluruh siswa 69,24 masih dibawah standar nilai Kriteria Ketuntasan Minimal KKM yang ditetapkan yaitu 75 dikarenakan kebanyakan siswa masih kesulitan dalam mengerjakan soal-soal fisika yang lebih kompleks yang memerlukan kemampuan memecahkan masalah fisika. Jika kemampuan memecahkan masalah siswa tidak ditingkatkan, maka siswa tidak akan mampu menyelesaikan persoalanpersoalan fisika yang lebih kompleks. Untuk itu diperlukan model pembelajaran fisika 
yang dapat membantu siswa meningkatkan kemampuan memecahkan masalah.

Berdasarkan uraian diatas, dapat disimpulkan bahwa masalah yang mengakibatkan hasil belajar siswa pada mata pelajaran IPA fisika khususnya, rendah karena kebanyakan siswa kesulitan dalam mengerjakan soal-soal fisika yang lebih kompleks dan bosan siswa dalam pembelajaran diakibatkan tidak adanya laboratorium fisika dan sarana prasarana yang kurang. Permasalahan tadi dapat dicari suatu solusinya dengan menggunakan suatu strategi pembelajaran yang mampu meningkatkan hasil belajar. Oleh karena itu tujuan dari penelitian ini adalah mendeskripsikan kemampuan siswa dalam memecahkan masalah, hasil belajar siswa, dan aktivitas siswa setelah dilaksanakan model Problem Based Learning (PBL) berbantukan Program Adobe flash pada Materi Pokok getaran dan gelombang.

\section{METODE}

Jenis penelitian yang akan dilaksanakan yaitu penelitian diskriptif. Variabel bebas pada penelitian ini adalah Model Problem Based Learning (PBL). Sedangkan variabel terikat pada penelitian ini adalah kemampuan memecahkan masalah siswa, hasil belajar siswa dan aktivitas siswa.

\section{HASIL DAN PEMBAHASAN}

\section{Kemampuan Memecahkan Masalah Siswa}

Hasil analisis data pre-test kemampuan memecahkan masalah pada materi getaran dan gelombang yaitu nilai rata-rata pre-test kemampuan memecahkan masalah sebesar 18,42 . Kemudian kelas yang dijadikan sampel sebagai penelitian diberikan perlakuan pembelajaran dengan menggunakan model PBL berbantuan program Adobe flash sebanyak tiga kali pertemuan setelah diberi pembelajaran kelas yang dipilih menjadi sampel, diberikan post-test kemampuan memecahkan masalah.

Hasil post-test tersebut diperoleh nilai rata-rata post-test kelas yang dipilih menjadi sampel yaitu 53,79 kemudian selain itu, berdasarkan nilai rata-rata pre-test dan posttest kemampuan memecahkan masalah diperoleh gain rata-rata atau selisih rata-rata pre-test dan post-test kelas yang dipilih menjadi sampel sebesar 35,37 sementara $\mathrm{N}$ gain sebesar 0,43 dengan kategori sedang. Dari hasil nilai rata-rata pre-test, post-test, Gain dan N-gain kita dapat mengetahui bagaimana peningkatan kemampuan memecahkan masalah siswa sesudah dilaksanakan model PBL berbantukan program Adobe flash dapat dilihat dari hasil $\mathrm{N}$-gain.

\section{Hasil Belajar Kognitif Siswa}

a. Ketuntasan Individual

Hasil analisis tes hasil belajar siswa secara kognitif yang diukur sebanyak satu kali. Pada tabel 4.3 menyatakan yaitu tes hasil belajar siswa dari 21 siswa yang mengikuti ujian tes hasil belajar, 16 siswa dinyatakan tuntas dan 5 siswa dinyatakan tidak tuntas 
dikarenakan tidak mencapai standar ketuntasan disekolah sebesar 75 dan dari hasil post-test mengalami peningkatan ketuntasan dibandingkan dengan ketuntasan siswa sebelum diberikan pembelajaran menggunakan model PBL berbantukan program Adobe flash (pre-test) yaitu 0 siswa yang dinyatakan tuntas dan didapatkan ratarata nilai siswa sebesar 78,57.

Siswa mengalami peningkatan ketuntasan belajar dikarenakan dalam pembelajaran menggunakan model PBL siswa terbiasa mengerjakan soal tingkat tinggi seperti soal $C_{4}$ sehingga siswa dengan mudah mengerjakan soal yang levelnya lebih rendah. Selain itu, dilihat dari hasil analisis data pengamatan aktivitas siswa, siswa tersebut sangat aktif, bersemangat dalam melakukan percobaan dan menyelesaikan masalah pada LKS yng diberikan oleh guru.

\section{b. Ketuntasan Klasikal}

Tes hasil belajar setelah diterapkan model PBL berbantukan program Adobe flash sebesar $76 \%$ dan dinyatakan tuntas karena melebihi syarat kriteria ketuntasan minimal disekolah yaitu $\geq 75 \%$.Hal ini dikarenakan siswa antusias siswa dalam pembelajaran dan juga siswa dalam mengerjakan tes hasil belajar mengerjakannya dengan teliti. Selain itu dilihat dari hasil analisis data siswa tes hasil belajar mengalami peningkatan sedang $71,42 \%$ dan tinggi $4,76 \%$ hal itu juga mempengaruhi mengapa ketuntasan siswa secara klasikal tuntas.

Pada tabel 4.3 menunjukkan bahwa hasil post-test THB terdapat lima orang siswa tidak tuntas dari kelima orang tersebut 3 orang siswa mendapatkan hasil yang sangat jauh dibawah standar KKM yang di tentukan di Sekolah MTs Islamiyah Palangka Raya yaitu yang bernama $\mathrm{AC}, \mathrm{AN}$, dan AQ dikarenakan mereka pada saat pembelajaran mereka tidak sepenuhnya hadir dari RPP1 RPP 3 sehingga ketinggalan pelajaran khususnya pada materi gelombang.

Pada tabel 4.4 menunjukkan bahwa hasil nilai pre-test dan post-test soal tes hasil belajar kognitif siswa mengalami peningkatan dengan berbagai kategori yaitu tinggi, sedang dan rendah. Dari 21 orang siswa 11 orang siswa dengan kategori tinggi, 9 orang siswa dengan kategori sedang dan 1 orang dengan kategori rendah. Untuk nilai persentase peningkatan hasil belajar kognitif siswa dari 21 orang siswa 52,38\% dengan kategori tinggi, 42,86\% dengan kategori sedang dan 4,76\% dengan kategori rendah.

Hasil nilai persentase peningkatan kemampuan memecahkan masalah siswa dengan kategori tinggi, sedang dan rendah dapat digambarkan dalam bentuk diagram lingkaran gambar 4.9 dibawah ini.

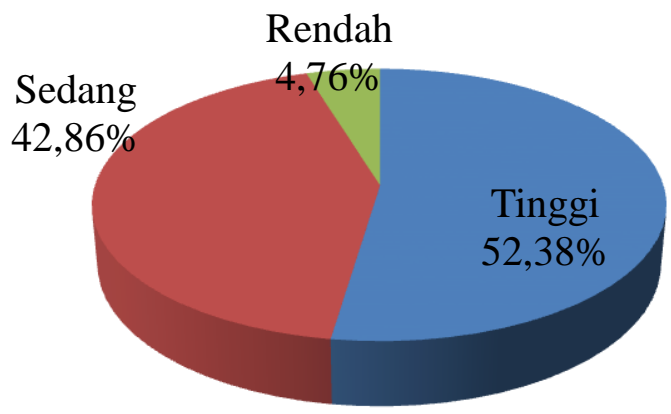

Gambar 1. Peningkatan Hasil Belajar Kognitif Siswa 
Hasil dari pre-test adalah nilai rata-rata dari kelas yang dipilih menjadi sampel penelitian sebelum diberi perlakuan sebesar 39,12. Kemudian kelas yang dipilih menjadi sampel diberikan pembelajaran menggunakan model $P B L$ berbantukan program Adobe flash sebanyak tiga kali pertemuan setelah diberi pembelajaran kelas yang dipilih menjadi sampel diberikan post-test hasil belajar.

Hasil post-test tersebut diperoleh nilai rata-rata post-test kelas yang dipilih menjadi sampel yaitu 78,57. Kemudian selain itu, berdasarkan nilai rata-rata pre-test dan posttest hasil belajar diperoleh gain rata-rata atau selisih rata-rata pre-test dan post-test kelas yang dipilih menjadi sampel sebesar 39,46 sementara N-gain (Peningkatan hasil belajar sesudah diberikan pembelajaran) sebesar 0,65 dengan kategori sedang.

\section{Aktivitas Siswa}

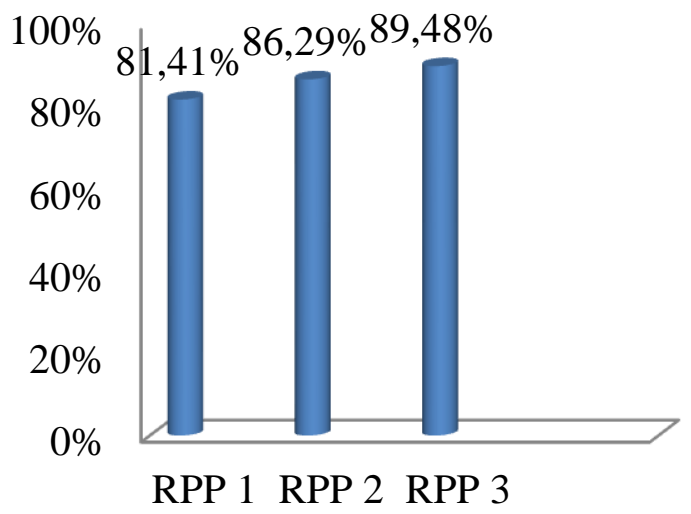

Gambar 2. Nilai Rata-rata Aktivitas Siswa
Gambar 2 di atas menunjukkkan bahwa aktivitas siswa dalam pembelajaran menggunakan model PBL dari RPP 1 sampai RPP 3 mengalami peningkatan.

Secara keseluruhan aktivitas siswa dari RPP 1 - RPP3 memperoleh persentase sebesar 85,73 dengan kategori sangat baik artinya siswa yang dijadikan sampel sangat aktif mengikuti proses pembelajaran fisika menggunakan model PBL.

\section{SIMPULAN}

1. Nilai rata-rata pre-test kemampuan memecahkan masalah sebelaum dilaksanakan pembelajaran model problem based learning (PBL) berbantukan program adobe flash sebesar 18,42 sementara nilai rata-rata pos-test kemampuan memecahkan masalah setelah dilaksanakan pembelajaran model problem based learning (PBL) berbantukan program adobe flash sebesar 53,79. Analisis NGain didapatkan nilai sebesar 0,43 dengan kategori sedang jadi peningkatan kemampuan memecahkan masalah setelah dilaksanakan model problem based learning (PBL) berbantukan program adobe flash adalah sedang.

2. Dari data posttest dengan menganilis menggunakan program microsof exel menggunakan rumus ketuntasan belajar individual dan ketuntasan klasikal didapatkan hasil persentase ketuntasan individual $76 \%$ tuntas dan $24 \%$ tidak tuntas, secara klasikal dikatakan tuntas karena melebihi syarat kriteria 
ketuntasan minimal disekolah yaitu $\geq 75 \%$. Nilai rata-rata pre-test hasil belajar kognitif siswa sebelum dilaksanakan pembelajaran model problem based learning (PBL) berbantukan program adobe flash sebesar 39,12 sementara nilai rata-rata pos-test hasil belajar kognitif setelah dilaksanakan pembelajaran model problem based learning (PBL) berbantukan program adobe flash sebesar 78,57 dan dari hasil analisis Uji $\mathrm{N}$-Gain didapatkan nilai sebesar 0,65 dengan kategori sedang jadi peningkatan hasil belajar kognitif setelah dilaksanakan model problem based learning (PBL) berbantukan program adobe flash adalah sedang.

3. Penilaian aktivitas siswa pada pembelajaran menggunakan model problem based learning (PBL) berbantukan program adobe flash didapatkan persentase nilai rata-rata aktivitas siswa sebesar $85,73 \%$ dengan kategori sangat baik, artinya siswa yang dijadikan sampel sangat aktif mengikuti proses pembelajaran fisika menggunakan model problem based learning (PBL) berbantukan berbantukan program adobe flash.

\section{DAFTAR PUSTAKA}

$\begin{array}{ccrr}\text { Annovasho J \& } & \text { Budiningarti } & \text { H. } & 2014 . \\ \text { Pengaruh } & \text { Penggunaan } & \text { Model } \\ \text { Pembelajaran } & \text { Berdasarkan } & \text { Masalah } \\ \text { terhadap Hasil } & \text { Belajar Siswa } & \text { Kelas X } \\ \text { Peminatan MIPA pada Pelajaran Fisika }\end{array}$

Baureno Bojonegoro. Inovasi Pendidikan

Fisika, 3(3): 20-26.

Trianto. 2010. Model Pembelajaran Terpadu, Jakarta: Bumi Aksara.

Nurlaila N, Suparmi S, Sunarno W. 2013. Pembelajaran Fisika dengan PBL Menggunakan Problem Solving dan Problem Posing ditinjau dari Kreativitas dan Keterampilan Berpikir Kritis Siswa. Jurnal Inkuiri, 2(2): 114-123

Setiawan GC. 2012. Penerapan Model Pembalajaran Problem Based Learning (PBL) disertai media computer macromedia flash. Jurnal Pembelajaran Fisika, 1(2), 245-250

Yamin. 2008. Paradigma Pendidikan Konstruktivistik, Jakarta: Gaung Persada Press.

Juniarti E, Medriati R, Hamdani D. 2014. Penerapan Model Problem Based Learning (PBL) Untuk Meningkatkan Kemampuan Pemecahan Masalah Fisika Siswa Pada Materi Fluida di Kelas XI IPA2 SMA Negeri 5 Kota Bengkulu. Skripsi. Universitas Bengkulu. 